\title{
Microneedling as a monotherapy in treatment of male androgenetic alopecia
}

\author{
Essam A. Nada, RehamEzz El-Dawla, Wafaa M. Abd El-Maged Ashraf A. Abd El-Latif, \\ Marwa A. Abo Elmagd, \\ Department of Dermatology, Venereology and Andrology
}

\section{Introduction}

Androgenetic alopecia (AGA) is the result of progressive, patterned hair loss that occurs when genetically predisposed individuals are exposed to androgens. The psychosocial impact of AGA may negatively affect patient's quality of life andcan lead to personal social and job-related problems ${ }^{(\mathbf{1})}$. Also; AGA can cause indirect physical harm to some patients, such as sunburn as a result of hair loss and exposure to ultraviolet light ${ }^{(2)}$.Moreover; AGA is reportedly associated with increased incidence of myocardial infarction, hypertension and hypercholesterolemia ${ }^{(3)}$.

Drug therapies for AGA approved by the FDA are limited to topical minoxidil and oral FIN with efficacy varies between $40 \%$ and $60 \%{ }^{(4)}$. Multiple factors are implicated in the pathogenesis of AGA which involves not only DHT but also inflammation, genes, signalling pathway, stimulatory pathways like Wnt/B catenin, and growth factors ${ }^{(5)}$. The existing conventional therapies (i.e. FIN and minoxidil) fail to target all of them ${ }^{(6)}$.

Microneedling $(\mathrm{MN})$ is a relatively new minimally invasive procedure involving controlled puncturing of the skin by rolling with miniature fine needles ${ }^{(7)}$. It showed efficacy in some dermatological conditions including post-acne scars ${ }^{(8)}$, other scars ${ }^{(9)}$, pigmentary disorders ${ }^{(\mathbf{1 0})}$, and as a method of drug delivery ${ }^{(11)}$.

The demand for new treatment techniques for AGA is growing, various procedures like mesotherapy, MN, platelet rich plasma, low laser light therapy, and stem-celltherapy are under active investigation ${ }^{(12)}$. MN creates multiple microchannels and increases transdermal penetration of drugs, facilitating higher concentration in dermis ${ }^{(\mathbf{1 3})}$.
Scalp needling also stimulates blood flow around blood starved hair follicles and gently exfoliates dead skin cells ${ }^{(14)}$.ScalpMN also induces hair regrowth by the following: release of growth factors through platelet activation and skin wound regeneration mechanism, activation of hair follicle stem cells in the hair bulge area under wound healing conditions which is caused by $\mathrm{MN}$, and overexpression of hair growth-related genes, vascular endothelial growth factors, $\beta$ catenin, Wnt3a, and Wnt10 $\mathrm{b}$ as documented in animal studies ${ }^{(\mathbf{6})}$.

The use of MN in combination with minoxidil showed promising results in treatment of AGA ${ }^{(6)}$. Furthermore; the addition of $\mathrm{MN}$ to minoxidil and oral FIN improved AGA in patients who were resistant to minoxidil and oral FIN ${ }^{(15)}$. To the best of our knowledge; the use of $\mathrm{MN}$ as monotherapy hasn't been previously reported.This study was designed to evaluate the efficacy and safety ofMN as a monotherapy in treatment of male AGA.

\section{Patients and methods:}

After approvalof this study by Ethical and Research committees at Faculty of Medicine, Sohag University; 15 male patients complaining of progressive hair loss diagnosed as AGA were included.All patients assigned informed written consent.

\section{Exclusion criteria}

Exclusion criteria included patients with other forms of alopecia including telogen effluvium, alopecia areata, those with dermatological or systemic illness known to cause diffuse hair loss (as thyroid disorders or anemia), and patients received minoxidil, any hair growth promoters in the past six months or those underwent surgical hair transplantation. 
SOHAG MEDICAL JOURNAL

Vol. 22 No.1 Jan 2018
Patients on hormonal, androgenic or anti androgenic medications cytotoxic, and inhibitors of CYP3A4 (ketoconazole, verapamil, diltiazem, cimetidine, ciprofloxacin), and those on anticoagulant medications (aspirin, warfarin and heparin) or have skin disease with Koebner's phenomenon were also excluded.

Methods:All patients were subjected to:

\section{I- Initial evaluation}

Personal history was reported including the age, occupation, marital status, smoking, and residency. History of hair loss was discussed with all patients including onset, course and duration of hair loss, site of hair loss, and use of hair care cosmetics (dying, bleaching, and straightening).History of other skin diseases, systemic diseases or any medications was documented. Family history of a similar condition was reported. Full general examinationwas done searching for any signs of anemia. Scalp examination was performed as regards any signs of inflammation, scales, erythema or scarring.

\section{II- Evaluation of hair loss:}

II.1- Pull test:After instructing the patient not to wash hair for 24 hours; grasping a small clump about 60 hairs in the index, middle and thumb was done, with pulling hairs gently but with firm pressure. The shed hairs were counted and positive test was reported as more than 6 hairs shed ${ }^{(\mathbf{1 6})}$.

II.2- Grading of AGAaccording to Norwood-Hamilton scale ${ }^{(17)}$.

II.3- Digital photography: The patients were photo documented before and after six months of treatment. A picture of the frontoparietal region was obtained in each patient. Before the photograph was taken the patient's hair was combed in a consistent manner for each patient so that the balding area could be optimally viewed.

II.4- Trichoscopy: An epiluminescene digital microscope (compareview A/V; Version 1.5.09) was used in this study. Trichoscope has five magnification lenses of different magnification powers which are $\mathrm{x} 15, \mathrm{x} 30, \mathrm{x} 50, \mathrm{x} 150$ and $\mathrm{x} 200$ folds.A magnification of (x 50) was used to detect the density of the hair follicles, vellus and terminal hairs; while magnification of (x 200) was used to evaluate the caliber of the hair shaft.

The frontal area of the scalp of each patient underwent tricoscopic evaluation, before and six months after treatment (frontal area was defined as approximately $2 \mathrm{~cm}$ from the frontal hairline and $2 \mathrm{~cm}$ from the midline ${ }^{(\mathbf{1 8})}$. Trichoscopic images were taken at the same specific area in the frontal area of each patient.

IIITreatment

procedues:Microneedling was done using dermapen.

Dermapen is auto-stamp motorized meso machine; it is a pen like instrument with a handle, a disposable needle cartridge, having 12 needles arranged in rows, and a power button to turn the machine on and off. It has guides to adjust needle length (turning the guide clockwise, the needle length will be longer ranging from $(0.25 \mathrm{~mm}$ to $2 \mathrm{~mm}$ maximum).

Topical anesthesia with $4 \%$ lidocaine cream was carried out 30 minutes before the procedure to the frontal area of the scalp of each patient, after this period, the cream was removed with saline, and the antisepsis of the entire area to be treated was subsequently performed with alcoholic chlorhexidine. Then the area had been completely dried.

The affected area of the scalp was stretched and MN was carried out in vertical and horizontal directions for about four to five times, until mild erythema was noted. The used needle length was $1.25 \mathrm{~mm}$.

Treatment schedule: 13 sessions were done for each patient according to the following schedule:

$\mathrm{V}$ Once every week for eight weeks (week $0,1,2,3,4,5,6,7)$.

v Once every two weeks for one month (week 9, 11).

$\mathrm{v}$ Once every month for three months (week $15,19,23)$.

IV- Treatment assessment: Assessment was done monthly and one week after the last session $\left(24^{\text {th }}\right.$ week $)$ depending on: 
IV.1) Grading scale: according to NorwoodHamilton grading scale.

IV.2) Photographic assessment: Digital photos of the affected region were obtained from patients before starting treatment (baseline) and at the end of treatment .

IV.3) Phototrichoscope: All patients underwent trichoscopic evaluation. Hair images were taken at 50x and 200x fold magnifications at the same affected area in the scalp of each patient before and after six months of treatment with (measurements of the hair density, hair thickness and terminal/vellus hair ratio).

IV.4) Patient's self-assessment (Hair growth questionnaire):Patients assessed their scalp hair at the end of the study using a validated hair growth questionnaire containing four questions on treatment efficacy and three questions on satisfaction with appearance ${ }^{(\mathbf{1 9})}$ (Figure I).

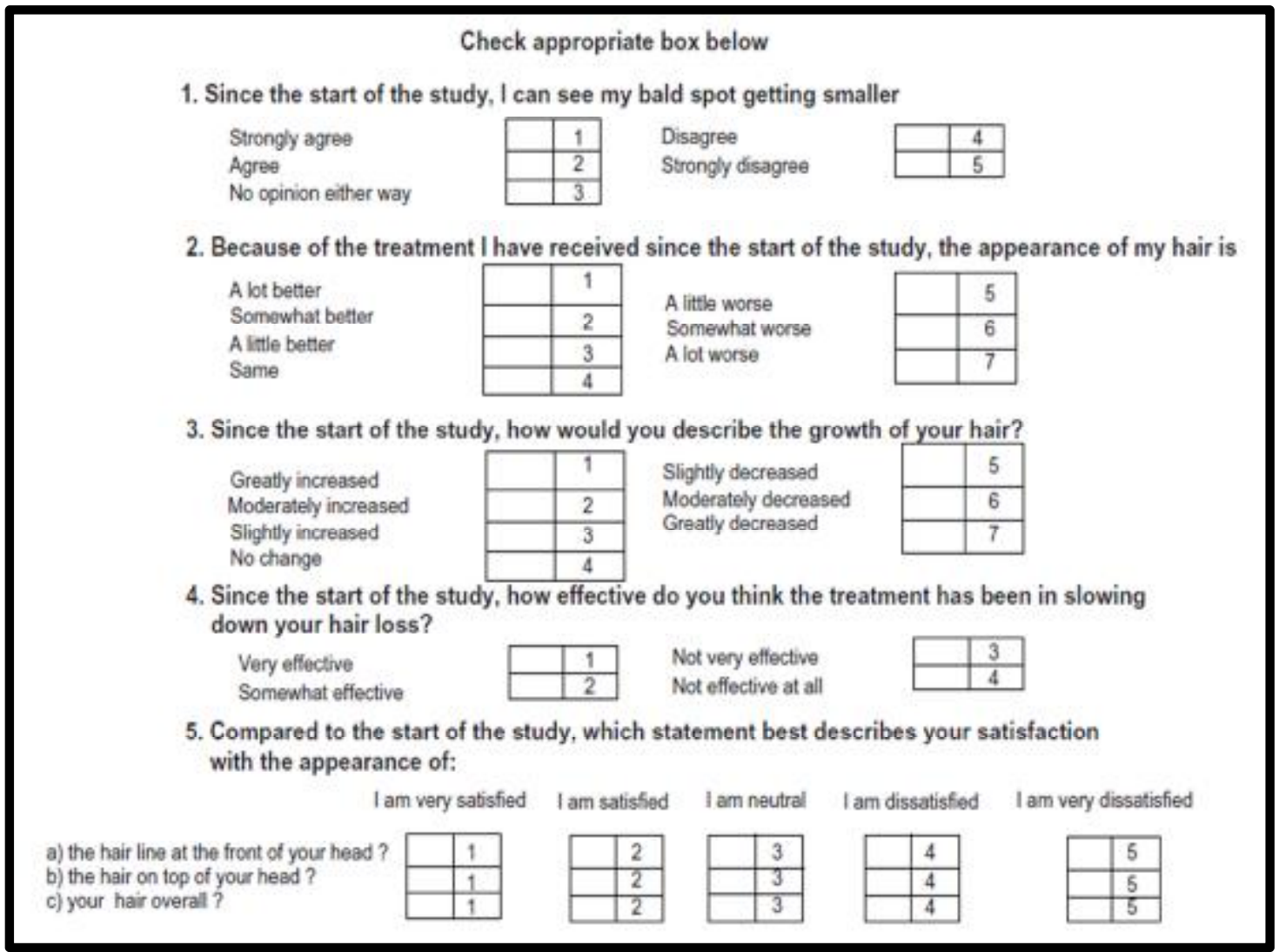

Figure I: Patient self-assessment questionnaire concerning changes in their scalp hair after treatment ${ }^{(\mathbf{1 9})}$.

IV.5) Investigator assessment: The hair density in the fronto-parietal region was compared to that observed before treatment using a 7-point rating scale: greatly decreased (-3), moderately decreased (-2), slightly decreased (-1), no change (0), slightly increased (+1), moderately increased $(+2)$, and greatly increased $(+3)^{(\mathbf{2 0})}$.

IV.6) Safety and tolerability assessment: Any side effects reported by the patient or noticed by the investigator was recorded.

\section{Statistical analysis:}

V Data was analyzed using STATA intercooled version 12.1.

v Numerical data were presented as mean and standard deviation (SD) values, for parametric numerical data, while Median and range for non-parametric numerical data.

$\checkmark$ For parametric data: Paired t-test was used to assess the statistical significance of the difference between two means measured twice. 
SOHAG MEDICAL JOURNAL

Vol. 22 No.1 Jan 2018
Microneedling as a monotherapy in treatment

Marwa A. Abo Elmagd
V For non-parametric data: Wilcoxon signed rank test was used assess the statistical significance of the difference of non-parametric variables measured twice

\section{Results}

The study included 15 male patients diagnosed as having AGA.The mean age \pm SD of the patients was $25.73 \pm 4.27$ years, with $10(66.67 \%)$ of them from rural areas.Family history of AGA was positive in $8(53.33 \%)$ of the patients.Most of the patients $13(86.67 \%)$ showed gradual onset of hair loss and progressive course was reported in all patients with mean disease duration \pm SDwas $4.33 \pm 2.23$ years. The highest prevalence of hair loss was in the frontal and vertex regions $(53.33 \%)$. Only 2 patients $(13.33 \%)$ had positive pull test and scales were found in 3 patients $(20 \%)$.

There was small decline in hair density but with no significant difference between hair density at the baseline and at $6^{\text {th }}$ month. There was no significant difference between hair caliber at the baseline and at $6^{\text {th }}$ month. There was mild increase in terminal/vellus ratio, with no significant difference between terminal/vellus ratio at the baseline and at $6^{\text {th }}$ month (Table 1 ).

Table 1: Results of phototrichoscopeof the study population $(n=15)$ before and after treatment.

\begin{tabular}{|c|c|c|c|c|c|}
\hline Variables & At baseline & After treatment & Change & $\begin{array}{c}\text { Percent of } \\
\text { change }\end{array}$ & $\begin{array}{c}* \mathbf{P} \\
\text { value }\end{array}$ \\
\hline $\begin{array}{l}\text { Hair density: } \\
\text { Mean } \pm \text { SD } \\
\text { Median (range) }\end{array}$ & $\begin{array}{l}189.07 \pm 143.1 \\
187.5(6-467) \\
\end{array}$ & $\begin{array}{c}180 \pm 130.48 \\
150(12-410) \\
\end{array}$ & $\begin{array}{l}{[-9.07] \pm 30.30} \\
0.5([-87]-22) \\
\end{array}$ & $-4 \%$ & 0.65 \\
\hline $\begin{array}{l}\text { Hair Caliber: } \\
\text { Mean } \pm \text { SD } \\
\text { Median (range) }\end{array}$ & $\begin{array}{c}0.020 \pm 0.016 \\
0.018(0.001-0.05)\end{array}$ & $\begin{array}{c}0.020 \pm 0.013 \\
0.015(0.004-0.045) \\
\end{array}$ & $\begin{array}{c}0.0003 \pm 0.015 \\
0.001([-0.027]-0.031)\end{array}$ & $3 \%$ & 0.69 \\
\hline $\begin{array}{l}\text { Terminal/vellushair } \\
\text { ratio: } \\
\text { Mean } \pm \mathrm{SD} \\
\text { Median (range) }\end{array}$ & $\begin{array}{c}2.72 \pm 3.88 \\
1.75(0.14-15.4)\end{array}$ & $\begin{array}{c}2.89 \pm 5.06 \\
1.45(0.13-20)\end{array}$ & $\begin{array}{c}0.17 \pm 1.40 \\
-0.005([-1.3]-4.6) \\
\end{array}$ & $4 \%$ & 0.73 \\
\hline
\end{tabular}

$* \mathrm{P}$ value $<0.05$ was significant.

As regards the investigator assessment; $13 / 15$ (86.67\%) of the patients showed no change in hair density, one patient $(6.67 \%)$ showed slight increase, and the last patient $(6.67 \%)$ showed slight decrease. Results of the patient self-assessment questionnaire are shown in table 2 . The only side effect was pain, which was reported in $10(66.67 \%)$ of the patients.

Table 2: Results of the patient self-assessment questionnaire in the study groups $(n=15)$.

\begin{tabular}{|c|c|c|c|}
\hline Variables & $\begin{array}{c}\text { Frequency } \\
\text { (Percentage) }\end{array}$ & Variables & $\begin{array}{c}\text { Frequency } \\
\text { (Percentage) }\end{array}$ \\
\hline $\begin{array}{l}\text { 1) Bald spot getting smaller: } \\
\text { Agree } \\
\text { No opinion either way } \\
\text { Disagree } \\
\text { Strongly disagree }\end{array}$ & $\begin{array}{c}0 \\
1(6.67 \%) \\
7(46.67 \%) \\
7(46.67 \%)\end{array}$ & $\begin{array}{l}\text { 2) Appearance of hair: } \\
\text { Somewhat better } \\
\text { A little better } \\
\text { Same } \\
\text { A little worse }\end{array}$ & $\begin{array}{c}0 \\
2(13.33 \%) \\
10(66.67 \%) \\
3(20.00 \%)\end{array}$ \\
\hline $\begin{array}{l}\text { 3) Hair growth: } \\
\text { Greatly increased } \\
\text { Moderately increased } \\
\text { Slightly increased } \\
\text { No change } \\
\text { Slightly decreased }\end{array}$ & $\begin{array}{c}0 \\
0 \\
6(40.00 \%) \\
7(46.67 \%) \\
2(13.33 \%)\end{array}$ & $\begin{array}{l}\text { 4) Slowing down hair loss: } \\
\text { Very effective } \\
\text { Somewhat effective } \\
\text { Not very effective } \\
\text { Not effective at all }\end{array}$ & $\begin{array}{c}0 \\
2(13.33 \%) \\
8(53.33 \%) \\
5(33.33 \%)\end{array}$ \\
\hline $\begin{array}{l}\text { 5) Satisfaction about hairline at the } \\
\text { front of the head: } \\
\text { Very satisfied } \\
\text { Satisfied } \\
\text { Neutral } \\
\text { Dissatisfied } \\
\text { Very dissatisfied }\end{array}$ & $\begin{array}{c}0 \\
0 \\
3(20.00 \%) \\
2(13.33 \%) \\
10(66.67 \%)\end{array}$ & $\begin{array}{l}\text { 6) Satisfaction about hair on } \\
\text { the top: } \\
\text { Very satisfied } \\
\text { Satisfied } \\
\text { Neutral } \\
\text { Dissatisfied } \\
\text { Very dissatisfied }\end{array}$ & $\begin{array}{c}\mathbf{0} \\
\mathbf{0} \\
\mathbf{0} \\
10(66.67 \%) \\
\mathbf{5}(\mathbf{3 3 . 3 3 \%})\end{array}$ \\
\hline $\begin{array}{l}\text { 7) Hair overall satisfaction: } \\
\text { Very satisfied } \\
\text { Satisfied } \\
\text { Neutral } \\
\text { Dissatisfied } \\
\text { Very dissatisfied } \\
\end{array}$ & $\begin{array}{c}0 \\
0 \\
0 \\
10(66.67 \%) \\
5(33.33 \%) \\
\end{array}$ & & \\
\hline
\end{tabular}




\section{Discussion}

The presence of AGAhas its negative effects on the patient's quality of life ${ }^{(\mathbf{1})}$.As multiple factors are implicated in the pathogenesis of AGA and the existing conventional therapies (i.e. FIN and minoxidil) fail to target all of them; the demand for new treatment techniques for AGA is growing.MN is one of these techniques that showed promising results in treatment of male $\mathrm{AGA}^{(\mathbf{6}, 15)}$.

In the current study; there was statistically insignificant decrease in hair density with mean percentage of change $(-4 \%)$ after treatment. This decrease can be taken as the "normal" hair loss with AGA, so patients go bald despite therapy. On the contrary; increased hair count was previously reported with use of $\mathrm{MN}$ in male $\mathrm{AGA}^{(6)}$. Authors found that $\mathrm{MN}$ along with minoxidil-treated group was statistically superior to minoxidil alone-treated group in promoting hair growth Concerning terminal/ vellus ratio; there was $4 \%$ mean percentage of change, which was mild and not statistically significant.The minimal improvement noticed might be

\section{References}

1. Hunt $\mathbf{N}$ and Mchale S: The psychological impact of alopecia.BMJ. 2005; 331(7522): 9513.

\section{Gubelin Harcha W, Barboza Martinez J, Tsai} TF, Katsuoka K, Kawashima M: A randomized, active- and placebo-controlled study of the efficacy and safety of different doses of dutasteride versus placebo and finasteride in the treatment of male subjects with androgenetic alopecia.J Am Acad Dermatol. 2014; 70(3): 489-98.e3.

3. Kim MW, Shin IS, Yoon HS, Cho S and Park HS: Lipid profile in patients with androgenetic alopecia: a meta-analysis.J Eur Acad Dermatol Venereol. 2017; 31(6): 942-51.

4. Gkini MA, Kouskoukis AE, Tripsianis G, Rigopoulos D and Kouskoukis K: Study of platelet-rich plasma injections in the treatment of androgenetic alopecia through an one-year period.J Cutan Aesthet Surg. 2014; 7(4): 213-9. in men. The mean change in hair count after 3 months was significantly greater for the MN group compared to the minoxidil group $\left(91.4\right.$ versus 22.2 respectively) ${ }^{(\mathbf{6})}$. This may be related to the value of $\mathrm{MN}$ as drug delivery method rather than mechanical effect.

Concerning hair shaft diameter in the present study; there was minimal statistically insignificant increase with mean percentage of change (3\%). The increase in the hair shaft diametergoes with the alleged role of trauma of $\mathrm{MN}$ in improvement of AGA.These results were consistent with a previous report of mild statistically insignificant increase in mean hair shaft diameter in patients receiving mesotherapy with saline, this goes with the alleged role of trauma of mesotherapy injection in improvement of $\mathrm{AGA}^{(21)}$.

attributed to stimulation of hair growth by the trauma which increases the blood supply to the HF, but it was minimal and not clinically or statistically significant

5. Leiros GJ, Attorresi AI and Balana ME: Hair follicle stem cell differentiation is inhibited through cross-talk between Wnt/beta-catenin and androgen signalling in dermal papilla cells from patients with androgenetic alopecia. $\mathrm{Br} \mathrm{J}$ Dermatol. 2012; 166(5): 1035-42.

6. Dhurat R, Sukesh M, Avhad G, Dandale A, Pal A: A randomized evaluator blinded study of effect of microneedling in androgenetic alopecia: a pilot study.Int J Trichology. 2013; 5(1): 6-11.

7. Fertig RM and Gamret AC: Microneedling for the treatment of hair loss? 2017.

8. Ayatollahi A, Hosseini H, Shahdi M, Ahmadnasrollahi S, Nassirikashani M: Platelet-rich Plasma by Single Spin Process in Male Pattern Androgenetic Alopecia: Is it an Effective Treatment? Indian Dermatol Online J. 2017; 8(6): 460-464. 
SOHAG MEDICAL JOURNAL
9. Costa IM and Costa MC: Microneedling for varicella scars in a dark-skinned teenager.Dermatol Surg. 2014; 40(3): 333-4.

10. Budamakuntla L, Loganathan E, Suresh DH, Shanmugam S, Suryanarayan S: A Randomised, Open-label, Comparative Study of Tranexamic Acid Microinjections and Tranexamic Acid with Microneedling in Patients with Melasma.J Cutan Aesthet Surg. 2013; 6(3): 139-43.

11. Iriarte C, Awosika O, Rengifo-Pardo $M$ and Ehrlich A: Review of applications of microneedling in dermatology.Clin Cosmet Investig Dermatol. 2017; 10: 289-98.

12. Motofei IG, Rowland DL, Baconi DL, Tampa M, Sarbu MI: Androgenetic alopecia; drug safety and therapeutic strategies.Expert Opin Drug Saf. 2018.

13. Escobar-Chavez JJ, Bonilla-Martinez D, Villegas-Gonzalez MA, Molina-Trinidad E, Casas-Alancaster N: Microneedles: a valuable physical enhancer to increase transdermal drug delivery.J Clin Pharmacol. 2011; 51(7): 96477.

14. Matarasso A, Pfeifer TM and Plastic Surgery Educational Foundation DC: Mesotherapy for body contouring.Plast Reconstr Surg. 2005; 115(5): 1420-4.

15. Dhurat $\mathbf{R}$ and Mathapati S: Response to Microneedling Treatment in Men with Androgenetic Alopecia Who Failed to Respond to Conventional Therapy.Indian $J$ Dermatol. 2015; 60(3): 260-3.

16. Shapiro J, Wiseman $M$ and Lui $H$ : Practical management of hair loss.Can Fam Physician. 2000; 46: 1469-77.

17. Sehgal VN, Kak R, Aggarwal A, Srivastava G and Rajput P: Male pattern androgenetic alopecia in an Indian context: a perspective study.J Eur Acad Dermatol Venereol. 2007; 21(4): 473-9.

18. Hillmann $K$ and Blume-Peytavi $U$ : Diagnosis of hair disorders.Semin Cutan Med Surg. 2009; 28(1): 33-8.
19. Barber B, Kaufman K, Kozloff R, Girman C and Guess H: A hair growth questionnaire for use in the evaluation of therapeutic effects in men.J Dermatol Treat. 1998; 9(3): 181-186.

20. Lucky AW, Piacquadio DJ, Ditre CM, Dunlap F, Kantor I: A randomized, placebocontrolled trial of $5 \%$ and $2 \%$ topical minoxidil solutions in the treatment of female pattern hair loss.J Am Acad Dermatol. 2004; 50(4): 541-53.

21. Sobhy N, Aly H, El Shafee A and EI Deeb M: Evaluation of the effect of injection of dutasteride as mesotherapeutic tool in treatment of androgenetic alopecia in males.Our Dermatol Online. 2013; 4(1): 40-5.1. Muller DC, Giles GG, Sinclair R, Hopper JL, English DR: Agedependent associations between androgenetic alopecia and prostate cancer risk.Cancer Epidemiol Biomarkers Prev. 2013; 22(2): 20915.

22. Hunt $\mathbf{N}$ and Mchale S: The psychological impact of alopecia. BMJ. 2005; 331(7522): 9513.

23. Gubelin Harcha W, Barboza Martinez J, Tsai TF, Katsuoka K, Kawashima M: A randomized, active- and placebo-controlled study of the efficacy and safety of different doses of dutasteride versus placebo and finasteride in the treatment of male subjects with androgenetic alopecia.J Am Acad Dermatol. 2014; 70(3): 489498.e3.

24. Kim MW, Shin IS, Yoon HS, Cho S and Park HS: Lipid profile in patients with androgenetic alopecia: a meta-analysis.J Eur Acad Dermatol Venereol. 2017; 31(6): 942-951.

25. Gkini MA, Kouskoukis AE, Tripsianis G, Rigopoulos D and Kouskoukis K: Study of platelet-rich plasma injections in the treatment of androgenetic alopecia through an one-year period.J Cutan Aesthet Surg. 2014; 7(4): 213-9.

26. Dhurat R, Sukesh M, Avhad G, Dandale A, Pal A: A randomized evaluator blinded study of effect of microneedling in androgenetic alopecia: a pilot study.Int J Trichology. 2013; 5(1): 6-11.

27. Arif $T$, Dorjay $K$, Adil $M$ and Sami M: Dutasteride in Androgenetic Alopecia: An Update.Curr Clin Pharmacol. 2017; 12(1): 3135. 
28. Abdallah M, El-Zawahry $K$ and Besar $H$ : Mesotherapy using dutasteride-containing solution in male pattern hair loss: A controlled pilot study.J Pan Arab Leag Dermatol. 2009; 20: $137-45$.

29. Sobhy N, Aly H, El Shafee A and El Deeb M: Evaluation of the effect of injection of dutasteride as mesotherapeutic tool in treatment of androgenetic alopecia in males.Our Dermatol Online. 2013; 4(1): 40-5.

30. Saceda-Corralo D, Rodrigues-Barata AR, Vano-Galvan $S$ and Jaen-Olasolo P: Mesotherapy with Dutasteride in the Treatment of Androgenetic Alopecia.Int $J$ Trichology. 2017; 9(3): 143-145.

31. Fertig RM and Gamret AC: Microneedling for the treatment of hair loss? 2017.

32. Dhurat $\mathbf{R}$ and Mathapati $\mathbf{S}$ : Response to Microneedling Treatment in Men with Androgenetic Alopecia Who Failed to Respond to Conventional Therapy.Indian $J$ Dermatol. 2015; 60(3): 260-3.

33. Shapiro J, Wiseman $M$ and Lui H: Practical management of hair loss.Can Fam Physician. 2000; 46: 1469-77.

34. Sehgal VN, Kak R, Aggarwal A, Srivastava G and Rajput P: Male pattern androgenetic alopecia in an Indian context: a perspective study.J Eur Acad Dermatol Venereol. 2007; 21(4): 473-9.
35. Barber B, Kaufman K, Kozloff R, Girman C and Guess H: A hair growth questionnaire for use in the evaluation of therapeutic effects in men.J Dermatol Treat. 1998; 9(3): 181-186.

36. Lucky AW, Piacquadio DJ, Ditre CM, Dunlap F, Kantor I: A randomized, placebocontrolled trial of $5 \%$ and $2 \%$ topical minoxidil solutions in the treatment of female pattern hair loss.J Am Acad Dermatol. 2004; 50(4): 541-53.

37. Mounsey AL and Reed SW: Diagnosing and treating hair loss.Am Fam Physician. 2009; 80(4): 356-62.

38. Andriole GL and Kirby R: Safety and tolerability of the dual 5alpha-reductase inhibitor dutasteride in the treatment of benign prostatic hyperplasia.Eur Urol. 2003; 44(1): 82-8.

39. Eun HC, Kwon OS, Yeon JH, Shin HS, Kim BY: Efficacy, safety, and tolerability of dutasteride $0.5 \mathrm{mg}$ once daily in male patients with male pattern hair loss: a randomized, double-blind, placebo-controlled, phase III study.J Am Acad Dermatol. 2010; 63(2): 252-8.

40. Amory JK, Wang C, Swerdloff RS, Anawalt BD, Matsumoto AM: The effect of 5alphareductase inhibition with dutasteride and finasteride on semen parameters and serum hormones in healthy men.J Clin Endocrinol Metab. 2007; 92(5): 1659-65.

41. Olsen EA: Female pattern hair loss.J Am AcadDermatol. 2001; 45(3 Suppl):s70-80 
SOHAG MEDICAL JOURNAL

Vol. 22 No.1 Jan 2018
Microneedling as a monotherapy in treatment Marwa A. Abo Elmagd 